\title{
ENVIRONMENTAL ASSET VALUATION METHOD USING AMUVAM: APPLICATION TO THE ASSESSMENT OF THE NATURAL PARK OF EBRO RIVER DELTA
}

\author{
Jerónimo Aznar ${ }^{1}$ \\ E-mail: jaznar@esp.upv.es \\ Vicente Estruch ${ }^{1}$ \\ E-mail: vestruch@esp.upv.es \\ Pablo Aragonés-Beltrán ${ }^{2} *$ \\ E-mail: aragones@dpi.upv.es \\ 1 Department of Economy and Social Sciences \\ 2 Department of Engineering Projects \\ Universidat Politècnica de València \\ Camino de Vera s/n 46022 Valencia (Spain)
}

\begin{abstract}
Nowadays there is widespread consensus that the environment provides social and public welfare, though the market is not able to value the benefits that these areas bring to soc iety. One of the basic parameters to demonstrate the importance of natural goods and resources is to calculate their monetary value. A common approach to valuate environmental goods and services is the multicriteria method AMUVAM (Analytic Multicriteria Valuation Method), based on the Analytic Hierarchy Method (AHP) and the Discount Cash Flow (DCF) method.

AMUVAM analyzes the preferences of a group of experts who identify the variables that add value to the natural resources and assets to be valued. The experts assign priorities to the variables in order to obtain a weight based on the value they bring to the asset. This is done through AHP (Analytic Hierarchy Process). Finally the variables whose present income can be quantified are identified and used to estimate the monetary value of the asset. This paper presents the results obtained with this method in the valuation of the Natural Park of the Ebro River Delta located in Spain.
\end{abstract}

Keywords: Economic valuation, environmental assets, Analytic Hierarchy Process, Discount Cash Flow.

\section{Introduction}

A wide range of approaches to environmental valuation involve placing monetary values on the environmental goods or services to be valued. The main valuation techniques in the field of Environmental and Ecological Economics are the Travel Cost method (Garrido et al., 1996), the Contingent Valuation method (Ciriacy-Wantrup, 1952), the Hedonic Pricing approach (Griliches, 1971). And the Energy and Emergy Analysis (Brown and Herendeen, 1996).

This paper presents a new method, the Analytic Multicriteria Valuation Method (AMUVAM), based on the combination of the Analytic Hierarchy Process (AHP) (Saaty, 1980) and Discount Cash Flow (DCF) analysis. AMUVAM is used to estimate a Monetary Indicator of the Total Economic Value (TEV) of an

\footnotetext{
* Corresponding author
} 
environmental asset and its components (direct use, indirect use, option, existence and bequest values). The method is applied to a case study for the valuation of the Ebro Delta Natural Park, located in the province of Tarragona, South Catalonia (Spain).

The application of multicriteria methods (AHP, CRITIC and Goal Programming) to Valuation and Assessment is very recent. In particular, Multicriteria techniques have been used to valuate works of art, industrial and agricultural land and urban properties (Aznar and Guijarro, 2007a, 2007b), (AragonésBeltrán et al, 2008), (Garcia-Melon et al., 2008), (Aznar, et al, 2010). The aim of this study and other research work being carried out is the application of multicriteria techniques to the valuation of environmental assets.

\section{Components of the Total Economic Value (TEV)}

The existing literature on economics and valuation distinguishes different types of values: Market Value, Probable Market Value, Use Value, Replacement Cost, and Target Value. In all these cases, the definition of Value refers to a specific market activity. However, the purpose of environmental economic valuation is not to obtain a market price as the relationship between the individual who valuates the environmental goods and the goods goes beyond the scope of use values, and as such it cannot be considered as a mere commodity. The economic valuation of environmental goods is not interested in its market price, because nobody is willing to buy or sell them, but in the social welfare or utility that it generates. Environmental economic valuation using the total economic value involves having an indicator of its contribution to social welfare for further comparison with other elements. Accordingly, the aim of the present work is to develop a new method to valuate the contribution of environmental assets to social welfare.

The Total Economic Value (TEV) is composed of the following values of environmental goods and services: direct use value, indirect use value, option value, existence value and bequest value. These values are defined as follows:

- Direct use value $(D U V)$ : value derived from the exploitation of environmental resources to satisfy human needs and priced in the market (concrete economic benefits derived from agriculture, livestock, logging, hunting, fishing, recreation, etc.).

- Indirect use value (IUV): value derived from their non consumptive uses, sometimes hardly observable and measurable, which are not directly priced in the market, but valued for the ir functional benefits such as recreational activities, nutrient cycling, soil retention, groundwater storage and recharge, flood control, support to other ecosystems, climate regulation, fixation of $\mathrm{CO} 2$, etc.

- Option / Quasi-option value $(O \mathrm{~V})$ : value derived from the ir potential future use (direct and indirect) which is difficult to predict based on current know ledge. For example, the discovery of new natural substances for drugs and medicines.

- Existence value $(E V)$ : value of an asset by virtue of being an essential resource for the conservation and development of biodiversity (variety of animal species, flora microhabitats, unique natural systems, cultural values, landscape, etc.).

- Bequest value $(B V)$ : the benefit is in ensuring that future generations will be able to inherit the same goods and services of the present generation, i.e. the value that is assigned to an environmental asset given that future generations have the opportunity to use and enjoy it. It is also known as heritage value.

Of all the values that make up the TEV, only DUV can be expressed in monetary units as it includes priced market activities, and by knowing the income they generate, their value can be calculated. The other TEV values (IUV, OV, EV and BV) are by their nature, difficult to quantify in monetary units. 


\section{Steps of the multicriteria method for environmental valuation.}

The procedure for the application of the multicriteria approach to the valuation of an environmental asset is as follows:

a) Step 1: Identify the components of TEV that are intrinsic to the asset (not always all types of values are intrinsic to a particular asset). This is essential to determine the pivot value through which TEV is estimated.

b) Step 2. Select a panel of experts with extensive knowledge of the asset to value. The experts should represent the various stakeholders with an interest in the asset to be valued (asset managers, naturalists, ecologists and biodiversity specialists, user representatives: hunters, farmers, tourism managers, etc.).

c) Step 3. Weight the TEV components present in the asset to be valued using AHP. The experts' judgments are obtained through a questionnaire of pairwise comparisons according to the level of importance assigned by the experts to the different values that make up the TEV. The model uses the comparison Saaty's scale. The experts' individual judgments are aggregated by geometric mean obtaining a single vector of priority.

d) Step 4. Select the TEV component that is priced in the market (the pivot value). In this step the TEV component directly related to the market is identified and an actual monetary value is obtained for that specific TEV component through any conventional method (comparative or discounted value).

e) Step 5. Calculate the economic value of each TEV component. Knowing the monetary value of the TEV component calculated in Step 4, the partial values of the other TEV components (IUV, $\mathrm{OV}, \mathrm{EV}, \mathrm{BV}$ ) can be calculated from the eigenvector of priorities for the TEV components (Step 3 ) that defines the relative proportion of the different values of the asset under analys is.

f) Step 6. Calculate the Total Economic Value Indicator. This indicator is obtained by the sum of all partial values calculated in Step 5 It gives the TEV value of the environmental asset under analysis. The value obtained from the TEV should not be considered a market price but an Indicator of the environmental asset value, the additivity of the partial values can be accepted as a proxy of its actual value (Mogas et al., 2006).

\section{Case study}

\subsection{Description of the Ebro Delta Natural Park}

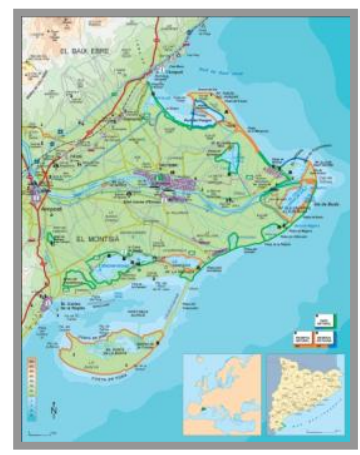

Figure 1. Location of Ebro Delta Natural Park

The Ebro Delta Natural Park is a highly anthropomorphic natural area and is one of the largest wetland areas in the Mediterranean region (RAMSAR Convention). It is located to the south of Catalonia (Spain), has an area of 8,445 ha and is one of the most important wetlands in the Mediterranean region, along with the Camargue (France) and Doñana National Park (Spain). About $80 \%$ of the Park's area is devoted to 
agriculture, mainly rice fields and recently to tourism. About one million tourists visit the Park every year. Other important activities are fishing and fish farming. Figure 1 shows the location of the Ebro Delta Natural Park

\subsection{Panel of Experts}

There are a large number of stakeholders in the Park with diverse interests. The Park has a Governing Board that includes representatives of the different interest groups. For the identification and weighting of the TEV components, a panel of 20 experts with extensive knowledge of the Park was formed including former and present members of the Park's Governing Board. The panel was formed by Ebro Delta munic ipal representatives, the President of the Park's Governing Board, the Director of the Ebro Delta Natural Park, technicians and researchers of the Park, staff, members of environmental organizations, farmers and fishermen.

\subsection{Identification and weighting of the TEV components}

Next, the identified TEV components (Figure 2) were weighted using the AHP method. For this end an individual questionnaire was designed to determine the experts' preferences regarding each component as compared to the others of the same level. The individual judgments were aggregated by the geometric mean method (Saaty and Peniwati, 2007). The experts answered the questionnaire at their place of work and it took them about 25 minutes to complete the questionnaire. Table 1 shows the aggregate weight of the sub-components of the TEV for the Ebro Delta Natural Park

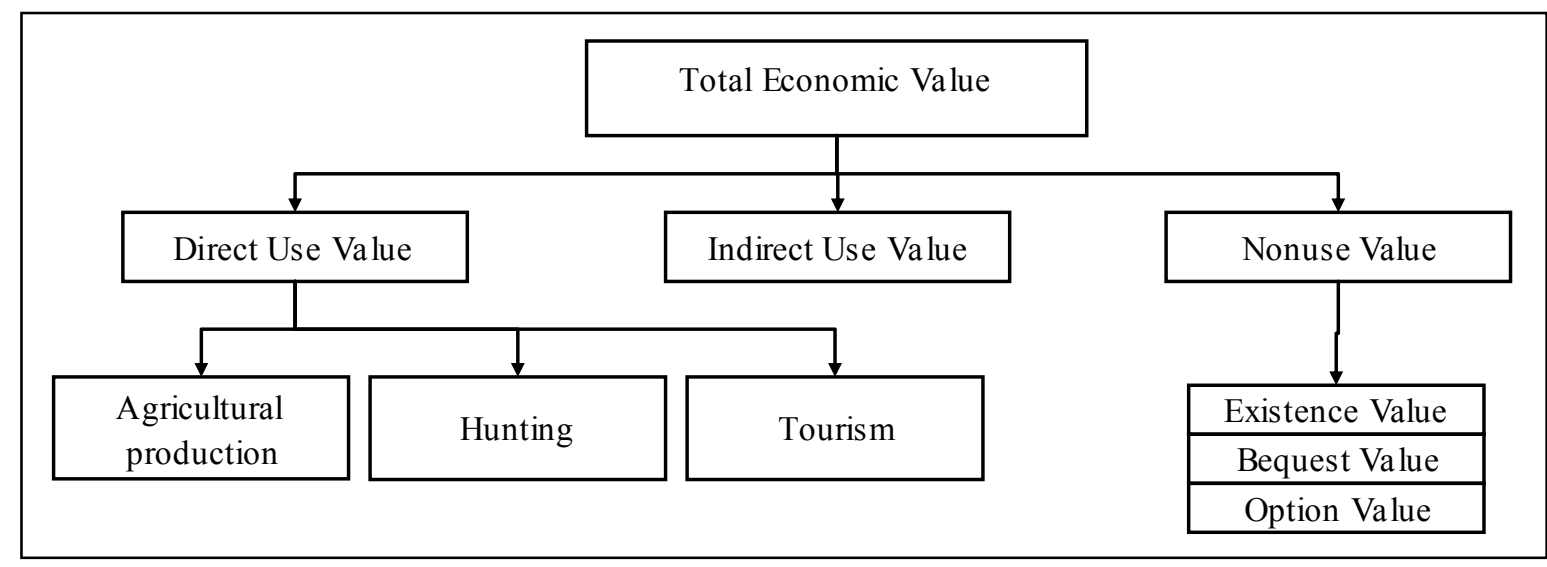

Figure 2. TEV components

Table 1. Aggregated weights of the TEV components

\begin{tabular}{|l|l|c|l|c|}
\hline & & Local Weight & & Local Weight \\
\hline \multirow{4}{*}{$\begin{array}{l}\text { TOTAL } \\
\text { ECONOMIC }\end{array}$} & Direct Use Value & 0,49 & Agricultural production & 0,55 \\
\cline { 3 - 5 } VALUE & & & Hunting & 0,09 \\
\cline { 3 - 5 } & & & Tourism & 0,36 \\
\cline { 2 - 3 } & Indirect Use Value & 0,25 & \multicolumn{2}{|c}{} \\
\cline { 2 - 3 } & Nonuse Value & 0,26 & \multicolumn{2}{|c}{} \\
\hline
\end{tabular}

\subsection{Estimation of the Direct Use Value (DUV).}

First the actual value of the economic benefits of the Park as a result of the agricultural production (essentially rice) (3806.93 ha) was calculated. The analys is of the economic data obtained from statistical production databases, agricultural cooperatives and the Governing Board of the Park can be seen in Table 2. The figures indicate revenues and expenses per hectare, total area and estimated annual benefits. 
Table 2 Economic value of the agricultural production

\begin{tabular}{|c|c|c|c|}
\hline Revenues (€/ha ) & Expenses (€/ha ) & Area (ha) & Income (€) \\
\hline 2896,76 & 2315,61 & 3806,93 & $2.212 .397,37$ \\
\hline
\end{tabular}

Taking into account a discounted income rate of $3 \%$ the present value is:

$$
V=\frac{G}{r}=\frac{2.212 .397}{0,03} \cong 73.746 .579 €
$$

Where $\mathrm{V}$ is the value of the Park resulting from rice production. As the economic value of rice has a significance of 0.55 compared to the other two components of the direct use value, DUV can be calculated as:

$$
\text { VUD }=73.746 .579 / 0,55=134.084 .689 €
$$

The value of hunting and tourism can be estimated by applying the respective weight of each value to DUV. In this way the economic values of the components of DUV can be obtained (Table 3).

Table 3: Values of the components of DUV

\begin{tabular}{|l|c|c|}
\hline $\begin{array}{c}\text { Components of the Direct } \\
\text { Use Value }\end{array}$ & Aggregated weight & Value in $€$ \\
\hline Rice & 0,55 & 73.746 .579 \\
\hline Hunting & 0,09 & 12.067 .622 \\
\hline Tourism & 0,36 & 48.270 .488 \\
\hline \multicolumn{2}{|l}{ TOTAL DIRECT USE VALUE } & 134.084 .689 \\
\hline
\end{tabular}

\subsection{Estimation of the Total Economic Value}

With the Direct Use Value and knowing that the weight of this component over the other two TEV components is 0.49 (Table 1), the calculation of the TEV is:

$$
\text { VET }=134.084 .689 / 0,49=273.642 .222 €
$$

The values of the components Indirect Use Value and Non-use Value are obtained by applying the weight of each component, respectively to the TEV. The values obtained are shown in Table 4.

Table 4: Values of TEV

\begin{tabular}{|l|c|c|}
\hline \multicolumn{1}{|c|}{ Values } & Specific weights & Values in $€$ \\
\hline Direct Use (A) & 0,49 & 134.084 .689 \\
\hline Indirect Use (B) & 0,25 & 68.410 .555 \\
\hline Non use (C) & 0,26 & 71.146 .977 \\
\hline \multicolumn{2}{|l|}{ TOTAL ECONOMIC VALUE } & $273.642 .222 €$ \\
\hline
\end{tabular}

The TEV is the estimated value of the total 8,445 ha of the Park, which gives a value of $32,402 € /$ ha

\section{Conclusions}

The new approach, AMUVAM, is based on the use of AHP, which is a technique used to establish priorities among the alternatives of a decision-making process, along with the conventional DFC valuation method, a valuation problem containing non-comparable assets. AHP prioritizes the different components of TEV and DFC is used to estimate the asset values of the activities included in the DUV. From this value and applying the weights obtained from AHP the values 
of TEV and its components are calculated. In the case study presented in this paper the pivot value of the DUV components is rice production.

Placing a monetary value on environmental assets is of great social interest. It is a way of expressing the value of preserving this asset from possible transformations and deterioration which is easily understood by all stakeholders. There is high pressure to transform the Natural Park of the Ebro Delta for use as residential buildings and hotels for tourism. The progressive depreciation of rice and agriculture in general is threatening this important wetland since the disappearance of the rice fields would gradually result in the drying of the wetland.

The approach presented in this paper involves the participation of different experts, so that the final value obtained is the result of consensus or aggregation of the opinions of all experts, but it is also possible to present a range of values that evidences the different interests of the members of the expert panel.

\section{REFERENCES}

Aragonés-Beltrán, P.; Aznar, J.; Ferrís-Oñate, J., García-Melón, (2008). M. Valuation of Urban Industrial Land: an Analytic Network Process Approach. European Journal of Operational Research 185: 322-339.

Aznar, J.; Guijarro, F. (2007a) Estimating regression parameters with imprecise input data in an appraisal context, European Journal of Operational Research 176(3), 1896-1907.

Aznar, J; Guijarro, F. (2007b) Modelling aesthetic variables in the valuation of paint ings: An interval goal programming approach, Journal of the Operational Research Society 58: 957-963.

Aznar, J., Ferrís-Oñate J., Guijarro, F., (2010), An ANP framework for property priceng combining quantitative and qualitative attributes. Journal of The Operational Research Society 61: 740-755

Brown, M.T. y Herendeen, R.A. (1996). Embodied energy analys is and Emergy analysis: a comparative view. Ecological Economics 19: 219-235.

Ciriacy-Wantrup, S.V. (1952). Resource Conservation: Economics and Policies, Agricultural Experiment Station. Berkeley, University of California Press.

García-Melón, M.; Ferrís-Oñate, J.; Aznar, J.; Aragonés-Beltrán, P.; Poveda-Bautista, R. (2008), Farmland appra isal based on the Analytic Network Process, Journal of Global Optimization 42 143-155.

Garrido, A., Gómez Limón, J., Lucio, V. y Múgica, M. (1996). Estudio del uso y valoración del Parque regional de la Cuenca Alta del Manzanares (Madrid) mediante el método del coste del viaje. En: Azqueta, D. y Pérez L. (eds) Gestión de Espacios protegidos: La demanda de Servicios Recreativos. McGraw-Hill, Madrid.

Griliches, S. (1971). Price Indexes and Quality Change. Studies in New Methods of Measurement. Harvard University Press, Massachusetts.

Mogas, J., Riera, P. y Bennett, J. (2006). A comparison of contingent valuation and choice modelling with second-order interactions. Journal of Forest Economics 12(1): 5-30.

Saaty, T. (1980). The Analytic Hierarchy Process. RWS Publications, Pitts burgh.

Saaty, T.L., \& Peniwati, K. (2007). Group decision-making: Drawing out and reconciling differences. Pittsburgh, PA: RWS Publications. 